\title{
The Role of Volunteer for the Management of Conservation-based Ecotourism in Clungup Mangrove Conservation Tambakrejo Village, Sumbermanjing Wetan Sub-District, Malang
}

\author{
Ferik Antyo Agus Wibowo ${ }^{1 *}$, Harsuko Riniwati ${ }^{2}$, Iwan Nugroho ${ }^{3}$ \\ ${ }^{1}$ Master Program of Enviromental Sciences, Postgraduate School, University of Brawijaya, Malang, Indonesia \\ ${ }^{2}$ Faculty of Fisheries and Marine Sciences, University of Brawijaya, Malang, Indonesia \\ ${ }^{3}$ Department of Agribusiness, Faculty of Agriculture, Widyagama University of Malang, Malang, Indonesia
}

\begin{abstract}
Clungup Mangrove Conservation (CMC) is the coastal area with the most complete ecosystem in Malang District. Since 2014, this place started to be known as the area of the conservation (tourism-based) with the best management, so it won the $1^{\text {st }}$ Adhibakti Minabahari with the category of Coastal Postponed Development. This achievement strongly supported by the role of volunteers who fight for the ecotourism management. Volunteer role is included the community involvement in the conservation activities in the region, starting from the CMC continues on the institutional establishment of ecotourism manager for CMC. The objectives of the study are to know and analyze the role of a volunteer on the management and the sustainability of the CMC ecotourism. The methods that were used are field observation, interview with the key stakeholders, and multi-dimension scale (MDS) method to analyze the sustainable management of CMC. The results of the survey revealed very important volunteer roles that involve 6 volunteer's efforts from the beginning to the creation of ecotourism management by initiating rehabilitation, the establishment of institutional, and create jobs. Increasing the quality of ecology is indicated with an increase in mangrove covering through rehabilitation projects, an increase in coral reefs covering and abundance coral fishes, and economic benefits of additional income for 108 local people who work in ecotourism sector in CMC area. The average value of volunteer's sustainability role in ecotourism management of CMC obtained with the acquisition of fourdimensional index value of 71.45. This value showed that aspects of ecology, social, economic, and institutional in ecotourism of CMC is fairly supported the sustainable development of ecotourism-based conservation in CMC.
\end{abstract}

Keywords: Clungup Mangrove Conservation, ecotourism, sustainable, volunteer.

\section{INTRODUCTION}

Volunteers in this study were people who started the movement of rehabilitation, initiate the establishment of institutional management of ecotourism, and create jobs for the local community ecotourism. The initial activity of the volunteers was area rehabilitation because the main goal of the volunteers is to restore and protect the natural resources that have been damaged in the coastal area. Until they finally known the potential of ecotourism in the rehabilitation area to create ecotourism activities that are more environmentally friendly and the impact of work opportunities for the community. Management of the Clungup Beach Tourism area also has a big influence on the surrounding community. The community that used to be farmers and fishermen now has other income as members of tourism awareness groups. The surrounding community can join the group so that the surrounding community can work and

\footnotetext{
${ }^{*}$ Correspondence address:

Ferik Antyo Agus Wibowo

Email : feriksunardi@gmail.com

Address : Postgraduate School, University of Brawijaya, MT Haryono No. 169, Malang 65145.
}

earn income from the management of tourist areas [1].

Conservation is one form of management of natural resources that have been damaged. There are various types of regional management; one type of management is Community-based Management. Mangrove conservation activities are carried out by reforestation or mangrove planting in areas with low mangrove cover, whereas coral reef conservation is conducted through coral reef transplantation and cleanup activities in the coral reef ecosystem area, either from waste or competing biota on coral reef ecosystems [2].

Most of these social organizations are traditionally managed. In the sense that their structures and operations are still traditionally dominated and 'family' oriented by 'altruistic' drives, whereas in order to achieve effective and efficient social services, it is not enough to rely solely on good intentions. Traditional cultural conditions that appear not only in the structure and management alone but it is still also embedded in their mentality which then appears into the behavior throughout the day [3]. 
Ecotourism is defined as a professionally packaged, trained, and educational travel tour as an economic sector/business that considers the cultural heritage, participation, and welfare of the local population as well as efforts to conserve natural resources and the environment [4]. The concept and implementation of ecotourism cannot be separated from the development of protected areas, especially the third pillar of ecotourism services considered as one of the entrances, as an economic approach, which examines and assesses the benefits of natural and environmental resources in conservation rules. Ecotourism services are the ultimate realms that package environmental and cultural services so as to generate benefits for many interests to support sustainable development.

Conceptually, ecotourism can be defined as a concept of sustainable tourism development that purposed to support environmental (natural and cultural) conservation efforts and increasing community participation in management, by providing economic benefits to local communities [5]. Ecotourism is defined as a responsible journey to a natural area that conserves the environment, sustains the prosperity of the local community, and involves interpretation and education. It includes business, education, environment, and culture of local people and efforts of conservation of natural resources and environment [6].

Clungup Mangrove Conservation (CMC) a littoral area with the most complete ecosystem in Malang district. CMC has 81 ha mangrove forest area and 117 ha for Greenbelt area, with the littoral geographic formation of mangrove vegetated mudflats, sand beaches with coral reef, and hillside panorama of south littoral of Java. These conditions CMS represent a complete tropical littoral ecosystem area.

There is little attention given in using mangroves as a place of recreation [7]. Some of the informants in this study note that this is because the mangrove environment is close to a muddy environment which is not suitable for tourism activities to enjoy nature. In addition to that, the dense vegetation and root structure of mangroves become a barrier for visitors to explore mangroves. Compared to the white sandy beaches and reef ecosystems, mangroves are considered less attractive destinations.

However, mangroves still have numerous biodiversity resources which potentially could be developed as natural attractions. One of the best opportunities is to ensure that mangrove-based tourism is implemented based on sustainable principles. East Java has a negative record regarding the loss of biodiversity, coastal forest deforestation, and especially mangrove exploitation. Therefore, promoting sustainable tourism in the mangrove environment is crucial.

POKMASWAS (Community based Wardens) Gatra Olah Alam Lestari (GOAL) and Bhakti Alam Sendangbiru Foundation consistent involvement in the restoration activities CMC makes this area into a pilot location of POKMASWAS that success both in East Java and National level in 2016. Besides conservation activities, POKMASWAS GOAL also manage the area as an ecotourism destination, where there are strict rules for visitors to keep the sustainability of biodiversity in CMC area. Since 2014, this place becomes well-known as a conservation area with the best management and got the $1^{\text {st }}$ place of Adhibakti Minabahari in 2015 in the category of Littoral Area Development of Tangguh (PKPT) and Kalpataru of East Java Province in the category of Pioneer environment in 2016. The purpose of this study is to find out how the role of the volunteer to ecotourism management in CMC and analyze the sustainability of ecotourism management in CMC tourism area.

\section{RESEARCH METHODS}

This research is descriptive qualitative. Data used in this research include primary data and secondary data that obtained from the management community; secondary data include the extent of biodiversity. While the primary data retrieval technique is done by observation and key stakeholder interview. Multidimensional scaling (MDS) was used to know the level of sustainability in CMC ecotourism management.

\section{Study Area}

The research location was conducted in Clungup Mangrove Conservation ecotourism area, Sendangbiru Hamlet, Tambakrejo Village, Sumbermanjing Wetan Sub-district, Malang District (Fig. 1). Administration of Sendangbiru Hamlet is located in Tambakrejo Village, included two hamlets namely Tambakrejo hamlet and Sendangbiru hamlet. Sendangbiru Hamlet is a littoral area with its coastal area facing Sempu Island. The length of the coastline of Malang District as a whole is $85.92 \mathrm{~km}$ with sea area 4 miles $\left( \pm 565.45 \mathrm{~km}^{2}\right.$ ) or water area of 12 miles $\left( \pm 1696.35 \mathrm{~km}^{2}\right)$. The length of the coastline of Sumbermanjing Wetan is around $27.02 \mathrm{~km}$, with sea area of 4 miles $\left( \pm 178.76 \mathrm{~km}^{2}\right)$ and the water area of 12 miles $\left( \pm 536.29 \mathrm{~km}^{2}\right.$ ) [8]. 


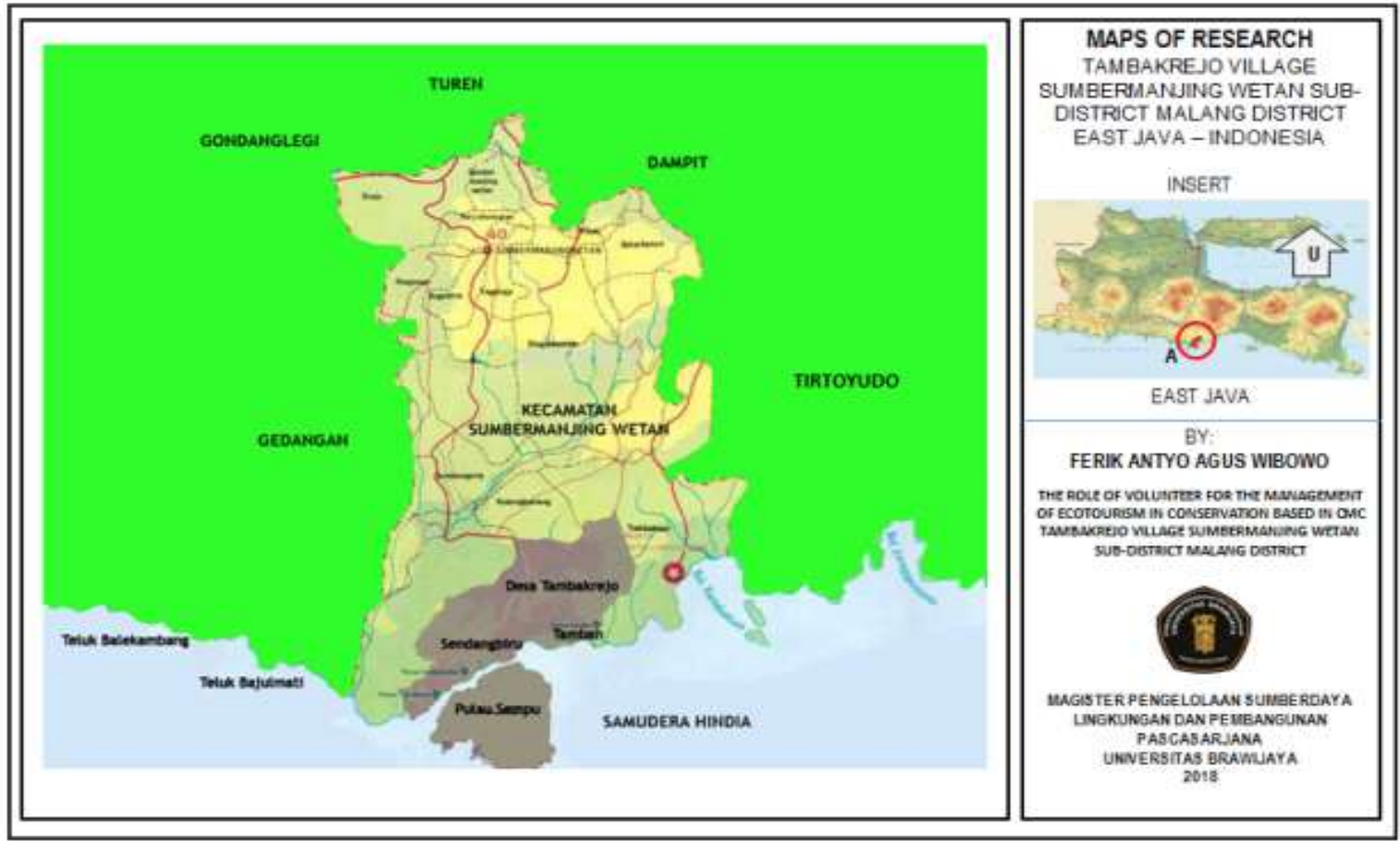

Figure 1. Research Location in Tambakrejo Village, Sumbermanjing Wetan Sub-district, Malang District

\section{Data Collection Methods Observation}

Observation activity in this research is used to collect data in the field directly. This observation was made by following the direct activities in the field, observe what activities are available in ecotourism areas of Clungup Mangrove Conservation. Seeing up to follow activities such as rehabilitation activities, monitoring of conservation areas, and following all existing activities in the ecotourism area.

\section{Interview}

Interview conducted in this research include a direct interview with key stakeholders and volunteers involved in ecotourism activities, namely Chairman of POKMASWAS GOAL and from Bhakti Alam Sendangbiru Foundation, Mr. STY, Mr. ICY, Mr. STS, Mr. Sdq, Mr. E and Mr. $\mathrm{Pi}$. These six respondents are volunteers who perform activities from the beginning of forming ecotourism activities in CMC.

\section{Questionnaire}

Questionnaire in this research is used to know the level of sustainability of ecotourism management in CMC. For field questionnaire data collection, there are four dimensions contained, namely ecological dimensions, social dimensions, economic dimensions and institutional dimensions.

\section{Data Analysis MDS}

Data from all of collection methods were analyzed using multidimensional scaling (MDS), which include four dimensions, i.e. ecological, social, economic, and institutional dimension. These dimensions will be on the analysis of the sustainability level through an existing attribute on the management society at the time of the study.

\section{RAPFISH}

The questionnaire that has been obtained from respondents then tabulated into RAPFISH software to measure the value of each dimension of sustainability and overall sustainability. Pitcher and Preikshot [9] classify the result of sustainability measurement attributes of each dimension. It is mapped into two bad-down point and good-up point. Classification or rating of sustainability status is divided into four dimension value (Table 1 ).

Table 1. Sustainability Status Category

\begin{tabular}{cccc}
\hline No & $\begin{array}{c}\text { Indeks Dimension } \\
\text { Value }\end{array}$ & Category & Information \\
\hline 1 & $00.00-24.99$ & Bad & Not Sustainable \\
2 & $25.00-49.99$ & Less & Less Sustainable \\
3 & $50.00-74.99$ & Enough & Fairly Sustainable \\
4 & $75.00-100.00$ & Good & Sustainable \\
\hline \multicolumn{3}{c}{ Source: Pitcher and Preikshot [9] }
\end{tabular}




\section{RESULT AND DISCUSSION}

Volunteers' role in CMC Ecotourism Area

The concept and implementation of ecotourism cannot be separated from the conservation area (protected area). In particular, the third pillar of ecotourism services is regarded as one of the entrances; as an economic approach, which examines and assesses the benefits of natural resources and environmental conservation principles. Ecotourism services are leading the pack of the real sector of environmental services and culture to produce benefits for many interests to support sustainable development [10].

Ecotourism may be better for the client, but it is very rarely better for local communities or conservation, as it generally uses the same flights, transport, and accommodation as all the other tourists visiting a national park. The consumer proposition is that the experience will be better because the guide will have the knowledge to find and interpret the wildlife a client wants to see. This clearly provides value to the client, but it does not contribute to the conservation of the species and habitats that are at the heart of the experience and the very motivation for travel in the first place. Ecotourists and voluntourists should take responsibility for the unintended consequences of their ecotourism and voluntourism, demand transparency, ask the challenging questions of producers and suppliers, complain if they fail to deliver on their promises, and hold them accountable publicly by seeking compensation as they would for any other form of travel and tourism [11].

Rehabilitation activities are volunteer's first work as they see the destruction of mangrove forests and coastal forests due to uncontrolled forest destruction after reforms in 1998. Looking at the conditions of natural resources that were severely damaged appeared to be initiated for rehabilitation activities which began in 2015, but through individual movements of personal awareness to take over mangrove forests and damaged coastal forests. The early management of CMC ecotourism is inseparable from the volunteers that have been struggled hard to develop CMC ecotourism management. The struggle of these volunteers began in 2012 with original purpose to make a movement at that time to protect natural resources from damage and rehabilitate the damaged natural resources. There are six volunteers who continue to survive rehabilitating the area through POKMASWAS GOAL formed in 2012.

The six volunteers are Mr. STY, Mr. ICY, Mr. STS, Mr. Sdq, Mr. E and Mr. Pi who are still doing rehabilitation activities and monitoring CMC areas that have been damaged even though no payments are earned. Until finally in 2014, they received visits from students and communities who want to enjoy the beauty of the beach within the conservation area. In the same year, appear an initiative to establish called Bhakti Alam Sendangbiru Foundation so that ecotourism management in the CMC area has legally legitimate institutions. Currently, members of the Bhakti Alam Sendangbiru Foundation amount 108 people who are empowered through employment.

From the result of observations and interviews directly to the volunteers, it can be known that since the beginning of management, the struggle is the absence of economic input value. However, the six volunteers are not discouraged to keep struggling to conserve the ecosystem in Sendangbiru area. These volunteers are a hero for Sendangbiru community because it can empower the community through employment absorption.

From the hard work of the volunteers resulted in the increase of mangrove forest cover that has been damaged, changes in the area of mangrove forest cover from 2010 to 2016 in brackets over 6 years has increased. This result cannot be separated from the conservation of mangrove forest in the area of Clungup Mangrove Conservation by the Society of Supervisors of Gatra Olah Alam Lestari (POKMASWAS GOAL) Bhakti Alam. POKMASWAS GOAL is also active in disseminating to local communities to participate in conservation activities. POKMASWAS GOAL has launched a program of liberation of coastal border line of 117 ha which is currently being controlled by forest encroachers to be compensated and returned to the State in order to obtain coastal protection function [12].

Table 1. Changes in Coverage of Mangrove from 2010 2016 in Clungup Mangrove Conservation Area

\begin{tabular}{cccc}
\hline No & Year & Large (Ha) & Change (Ha) \\
\hline 1 & 2010 & 3.015 & - \\
2 & 2013 & 3.303 & +0.288 \\
3 & 2016 & 4.131 & +0.828 \\
\hline
\end{tabular}

Source: Wonorengga [12] 
The role of volunteers in the ecotourism management in CMC is very huge. The volunteers with their spirit and sacrifice willing to spend their time and energy to rehabilitate the coastal area of Sendangbiru. They even think to restore the damaged forest to its natural function until it recovers. These efforts get results when people can get income from ecotourism activities in the conserved areas that have been restored. The community calls its fortune from nature.

\section{Management of CMC Ecotourism Area}

Establishment of the management system in CMC ecotourism area is also different from other tourist destinations. Manager apply strict systems and rules for visitors who will enter CMC ecotourism area because governance must be in accordance with the struggle, vision, and mission of the movement. The vision is living together with nature and the mission is building a society that loves the environment and establishes a conservation village community, by utilizing natural resource responsibly through community empowerment programs, and participates actively in the development of tourist village in East Java. Therefore, to protect the area from damage, then some rules was set for the tourist to enter the CMC ecotourism area, as follows.

1. Everyone who visits Tiga Warna beach is required for reservation to call center number (Telephone number: 08123339889 and SMS center: 082132677713), while no reservation required for Clungup and Gatra beach.

2. Any visitors with a destination other than Clungup or Gatra beach is required to use the service of a local guide.

3. Visitation to Tiga Warna beach has a maximum capacity of 100 people inside and maximum visit time just for 2 hours.

4. It is not allowed to free dive in the Marine Protected Area (Tiga Warna beach).

5. It is not allowed to swim in Savana beach, Mini beach and Batu Pecah beach.

6. Visitors at the Tiga Warna beach should not play in the water when the tide is low.

7. Visitors are forbidden to use shampoo and soap when rinsing their body in the Tiga Warna beach area.

8. All visitors of CMC who went to Tiga Warna area required a checklist process of incoming luggage and outcoming luggage.

9. Each motor vehicle can only enter up to post 1.
10. Carrying capacity:

a. Tiga Warna beach $=100$ people

b. Clungup beach $=300$ people

c. Gatra beach $=300$ people

11. The camping area is only provided at one point of Gatra beach with a maximum capacity of 75 tents (dome).

12. Clungup Mangrove Conservation area is closed for total visits every Thursday.

13. Clungup Mangrove Conservation area totally closed every $\mathrm{D} \pm 3$ at the beginning of fasting month (Ramadan) and $\mathrm{D} \pm 3$ on Eid Al-Fitr.

14. Clungup Mangrove Conservation area totally closed every year-end holidays from December $23^{\text {rd }}$ to January $4^{\text {th }}$.

15. It is not allowed to build permanent buildings or private buildings in the Clungup Mangrove Conservation of Tiga Warna area.

16. It is not allowed to sell outside the specified point.

\section{Sustainability Analysis}

Sustainability analysis of volunteer role in ecotourism management with conservationbased at CMC Tambakrejo Village was analyzed by Multi Dimension Scaling (MDS) method, by using RAPFISH software assistance. In this analysis, four dimension are used to measure the sustainability, i.e. ecological, social, economic and institutional dimensions.

The first step in determining the sustainability of CMC ecotourism by using MDS is to determine the dimensions to be used as well as the attributes corresponding to the research location. Then we also perform the attribute assessment based on the criteria of each dimension by giving a score on an ordinal scale. Influential attribute determined for total 35 attributes; with details of 12 attributes for ecological dimension, 16 attributes on the social dimension; 5 economic dimension attributes; 4 institutional dimension attributes. The results from the questionnaire were compiled according to the dimensions and attributes, based on the ordinal measurement scale to assign values. The summary of MDS-RAPFISH analysis result for these four dimension presented in Table 1.

Table 2. MDS Analysis Result

\begin{tabular}{lcc}
\hline \multicolumn{1}{c}{ Dimension } & Stress (S) & R-Square (R) \\
\hline Ecology & 0.2054 & 0.9227 \\
Social & 0.2465 & 0.9231 \\
Economy & 0.2464 & 0.9108 \\
Institutional & 0.2494 & 0.9191 \\
\hline
\end{tabular}

Source: Primary Data Processed, 2018. 
Reference that used as a basis for determining the goodness of the analysis result (Goodness-of-fit) in the MDS is value of stress less than or equal to 0.25 and R-Square more than 0.90. Based on Table 1, the value of four dimension stress used is smaller than 0.25 . Similarly, the R-Square is also show the value above 0.90 . Therefore, it can be said that this MDS analysis meets the Goodness-of-fit criteria so it is worthy to be discussed/analyzed further.

From analysis result using RAPFISH, we found that the result of 4 different dimensions combined into sustainability status diagram as shown in Figure 2. Figure 2 shows a combination of four dimensions to assess sustainability of the volunteer role in the development of conservation-based ecotourism in the CMC.

On average, the sustainability index value of these 4 dimension is 71.45 . This value indicate that ecological, social, economic and society aspect of the CMC ecotourism proved enough to support the sustainability of ecotourism development with conservation-based. Based on this diagram, if the index is getting out or close to 100 , it indicate a better sustainability status. Otherwise, if it gets deeper or closer to 0 , it show the worsening sustainability status. From these four dimension, the dimensions that have the worst sustainability index value are ecological and economic dimensions. It indicate that if the expected sustainability of conservation-based ecotourism development in CMC increases, it can be cultivated by improving the ecological and economic aspect first.

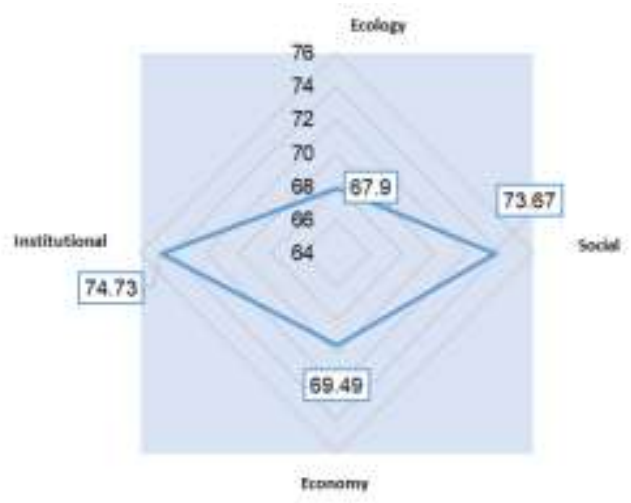

Figure 1.Sustainability status diagram Source: Primary Data Processed, 2018.

\section{CONCLUSION}

Volunteer's role in the management of CMC ecotourism is huge. The volunteers as the member of POKMASWAS since 2012 makes the conservation area in Sendangbiru become ecotourism management called Clungup Mangrove Conservation (CMC) area which we know to date. The volunteer trying to restore severely damaged littoral environment, until finally it can initiate the management of $\mathrm{CMC}$ ecotourism. The average value of sustainability status in CMC ecotourism is 71.45 . This value shows the sustainability of ecotourism management through four dimensions of ecology, social, economic and society is enough to support the sustainable development of ecotourism. However, it is necessary to improve the ecological and economic aspect to increase its sustainability status.

\section{ACKNOWLEDGEMENT}

Thank you to the CMC ecotourism area managers who have assisted in implementing the research, as well as for the Bhakti Alam Sendangbiru Foundation which has facilitated this research activities.

\section{REFERENCES}

[1] Yachya, A. N., Wilopo and M. K. Mawardi. 2016. Pengelolaan kawasan wisata sebagai upaya peningkatan ekonomi masyarakat berbasis CBT (Community Based Tourism) Studi pada kawasan wisata Pantai Clungup Kabupaten Malang). Jurnal Administrasi Bisnis 39(2), 107-116.

[2] Januarsa, I N. and O. M. Luthfi. 2017. Community based coastal conservation in Buleleng Bali. Economic and Social of Fisheries and Marine Journal 4(2), 166-173.

[3] Raharjo. 2010. Pengembangan sumber daya relawan pada organisasi pelayanan sosial studi literatur mengenai sistem pendidikan dan pelatihan sumber daya relawan. Padjajaran University. Bandung.

[4] Nugroho, I. 2011. Ekowisata dan pembangunan berkelanjutan. Pustaka Pelajar. Yogyakarta.

[5] Hadinoto, K. 1997. Perencanaan pengembangan destinasi pariwisata. University of Indonesia. Jakarta.

[6] TIES (The International Ecotourism Society). 2006. Fact sheet: global ecotourism. Updated edition, September 2006. Available at: www.ecotourism.org.

[7] Hakim, L., D. Siswanto and N. Makagoshi. 2017. Mangrove conservation in East Java: the ecotourism development perspectives. Journal of Tropical Life Science 7(3), 277285. 
[8] Office of Tambakrejo Village. 2016. Clungup Mangrove Conservation ecotourism area. Office of Tambakrejo Village. Tambakrejo.

[9] Pitcher, T.J. and D. B. Preikshot. 2001. Rapfish: a rapid appraisal technique to evaluate the sustainability status of fisheries. Fisheries Research 49(3), 255-270.

[10] Nugroho, I. 2007. Ekowiata: sektor riil pendukung pembangunan berkelanjutan. Majalah Perencanaan PembangunanBAPPENAS Jakarta XII (2), 44-57.

[11] Goodwin, H. 2015. Tourism, good intentions, and the road to hell: ecotourism and volunteering. Brown Journal of World Affairs xxii (1), 37-50.

[12] Wonorengga, Y. 2017. Analisis spasial dan temporal perubahan tutupan mangrove di kawasan Clungup Mangrove Conservation Bhakti Alam Sendang Biru, Kabupaten Malang. Thesis. Faculty of Fisheries and Marine Sciences, University of Brawijaya, Malang. 